\title{
Extended Shelf Life of Random Donor Platelets Stored for 7 Days in Platelet Additive Solution at Different Temperatures
}

\author{
Tulika Chandra $^{1}$, Ashish Gupta ${ }^{1,2}$, Ashutosh Kumar ${ }^{2}$
}

Background: Platelets are routinely stored in plasma for 5 days at an average temperature of $22^{\circ} \mathrm{C}$. In the present study, the shelf life of random donor platelets was extended by storing for 7 days with and without additive solution at temperatures of $22^{\circ} \mathrm{C}, 18^{\circ} \mathrm{C}$, and $16^{\circ} \mathrm{C}$.

Methods: Random donor platelets were stored in $100 \%$ plasma and $20 \% / 80 \%$ platelet additive solution. The data were compared using paired " $t$ "-test. The confidence limit was kept at $95 \%$, hence a " $p$ " $<0.05$ was considered to be statistically significant.

Results: $\quad$ Out of total 150 samples, 148 samples were analyzed and 2 were discarded due to the bacterial contamination on day 7 at $22^{\circ} \mathrm{C}$ without platelet additive solution. A significant difference in platelet count, platelet factor 3 (PF 3), glucose, lactate dehydrogenase (LDH), and platelet aggregation was observed on day $7(p<0.001)$ at $16^{\circ} \mathrm{C}$ in without platelet additive solution. In platelet additive solution, the mean values of platelet count, platelet distribution width (PDW), $\mathrm{LDH}$, and $\mathrm{pH}$ showed no significant difference on day 7 at $22^{\circ} \mathrm{C}, 18^{\circ} \mathrm{C}$, and $16^{\circ} \mathrm{C}$. Only significant differences were observed in the levels of mean platelet volume (MPV), PF 3, glucose, and platelet aggregation on day $7(p<0.001)$ at $16^{\circ} \mathrm{C}$ of the storage period.

Conclusion: Random donor platelets functions are better maintained in platelet additive solution as compared to plasma at a lower temperature of $18^{\circ} \mathrm{C}$ but not at $16^{\circ} \mathrm{C}$, on the $7^{\text {th }}$ day.

(Biomed J 2014;37:211-217)

Key words: days, platelet additive solution, random donor platelets, shelf life, temperatures

$\mathrm{P}$ latelets are the second most numerous corpuscles in the blood. They are routinely stored in plasma for 5 days at an average temperature of $22^{\circ} \mathrm{C}$. Research in the storage of platelets suggests that there are three fundamental quality standard parameters that must be considered for a proper evaluation of the effects of prolonging the shelf life of platelet concentrates, namely, platelet count (PLT), $\mathrm{pH}$ value, and absence of bacteria. ${ }^{[1]}$

\begin{abstract}
At a Glance Commentary
Scientific background of the subject

Platelets have a short half-life which creates a problem in their availability and inventory. Platelet functions, if maintained till 7 days without bacterial contamination, can be an important step for extending the shelf life of platelets from 5 to 7 days.
\end{abstract}

\section{What this study adds to the field}

Platelet additive solution can be added to avoid the problem of contamination and for maintaining platelet functions to the optimal level. This can be useful for changing the guidelines for extended shelf life of platelet concentrates.

\begin{abstract}
Platelets' functions should be better maintained in additive solutions with all the parameters necessary to establish their efficacy. Gulliksson (2000) ${ }^{[2]}$ highlighted some other characteristics in using an additive solution for substitution of plasma as a storage medium for platelet concentrates (PCs). The present study was conducted with an aim to extend the shelf life of random donor platelets stored for 7 days with and without additive solution at temperatures of $22^{\circ} \mathrm{C}, 18^{\circ} \mathrm{C}$, and $16^{\circ} \mathrm{C}$.
\end{abstract}

From the ${ }^{1}$ Department of Transfusion Medicine and Blood Bank, King George's Medical University, Lucknow, Uttar Pradesh, India; ${ }^{2}$ Department of Pathology, King George's Medical University, Lucknow, Uttar Pradesh, India Received: May. 24, 2013; Accepted: Jul. 26, 2013

Correspondence to: Dr. Tulika Chandra, Department of Transfusion Medicine and Blood Bank, King George's Medical University, Lucknow, Uttar Pradesh, India. Uttar Pradesh - 226 003, India. Tel: 91-9415755536; Fax: 91-522-258492; E-mail: tulikachandra@ rediffmail.com

DOI: $10.4103 / 2319-4170.117896$ 


\section{METHODS}

The study sample included 150 blood donors of both sexes from Department of Transfusion Medicine, King Georg's Medical University, Lucknow, Uttar Pradesh, India. Complete medical history of donors was taken to exclude any infection and disease in the collected samples.

\section{Study subjects}

The blood donors were selected after taking a detailed history and a complete examination regarding their eligibility criteria for blood donation. Donor's name, age, sex, occupation, caste, complete postal address, and contact number were recorded. Donors were deferred or accepted according to their medical history regarding chronic or acute diseases. Findings were further confirmed by physical examination of the donor. Blood was taken from a donor only after they were found to fulfill all the eligibility criteria of a healthy donor. Written consent was also taken from them prior to donation, regarding their acceptability for the tests to be carried out for the transfusion-transmitted diseases as well for the platelet function studies.

\section{Random donor platelets preparation}

The random donor platelets were prepared by platelet-rich plasma (PRP) method. ${ }^{[3]}$ Whole blood $(350 \mathrm{ml})$ was collected in anticoagulant citrate phosphate dextrose adenine (CPDA) triple blood bags (HL Hemopack, Hindustan Latex Ltd, Kerala, India). After a resting time of $30 \mathrm{~min}$, the whole blood was centrifuged in a Cryofuge 6000i (Heraeus-Kendro, Hanau, Germany) at $1750 \times g$ for $8 \mathrm{~min}$ at $22^{\circ} \mathrm{C}$ to obtain PRP. The obtained PRP was again centrifuged at $3850 \times g$ for 8 min under the same experimental conditions. After the final centrifugation, the supernatant platelet-poor plasma (PPP) was separated, and the residual pellet with the platelets was resuspended in a mean volume of $50 \pm 0.9 \mathrm{ml}$ of plasma. For storage of platelets in additive solution, between 10 and $15 \mathrm{ml}$ of plasma was left with the platelet concentrates and $8 \mathrm{ml}$ of additive solution was added for every $2 \mathrm{ml}$ of platelet concentrates to give an expected final concentration of $80 \%$ additive solution and $20 \%$ plasma. Random donor platelet was placed in a platelet incubator (Remi Instruments Ltd, Mumbai, India) with continuous agitation at 70 cycles/min during storage at different temperatures.

\section{Preparation of random donor platelets using platelet additive solution}

All the random donor platelets were stored in additive solution which had been standardized using the follow- ing constituents: sodium chloride (5.26 g) (Merck Pvt. Ltd, Mumbai, India), sodium gluconate (5.02 g) (Rolex Chemicals Industries, Mumbai, India), sodium acetate anhydrous (2.22 g) (Ranbaxy Fine Chemicals Ltd, New Delhi, India), potassium chloride ( $0.373 \mathrm{~g}$ ) (Ranbaxy Fine Chemicals Ltd), magnesium chloride hexahydrate (0.305 g) (Merck Pvt. Ltd), and sodium citrate (3.213 g) (Sisco Research Pvt. Ltd, Mumbai, India). All the constituents were dissolved in $1000 \mathrm{ml}$ of distilled water and steam sterilized. The $\mathrm{pH}$ of this additive solution was $7.2 .^{[4]}$

\section{Screening of blood and storage of platelet units}

All the blood units were screened for Hepatitis B virus (Hepalisa; J Mitra and Co. Pvt. Ltd, New Delhi, India), Hepatitis C virus (HCV Microlisa; J Mitra and Co. Pvt. Ltd), and Human Immunodeficiency Virus 1 and 2 (Microlisa-HIV; J Mitra and Co. Pvt. Ltd). The method used was enzyme-linked immunosorbent assay (Elisa plate washer version 3 and Elisa plate reader version no. 1.300; Robonik Pvt. Ltd, Navi Mumbai, India). Syphilis was tested by Rapid Plasma Reagin (RPR) method (Span Diagnostic Ltd, Surat, India).

\section{Assessment of PLT and functions}

Standard protocols were followed to assess platelets on day 0 , day 5 , and day 7 of storage. Samples were withdrawn under sterile conditions in biosafety cabinet grade 2. PLT, mean platelet volume (MPV), and platelet distribution width (PDW) were measured using automated cell counter (MS4, Blood cell counter; Anand Group, HD Consortium, Bangalore, India). Platelet functions were assessed by platelet factor 3 (PF 3) with kaolin and $\mathrm{CaCl}_{2} \cdot{ }^{[5]}$ Exactly $100 \mu \mathrm{l}$ of platelet-rich test plasma was added to $100 \mu \mathrm{l}$ of platelet-poor normal plasma in a test tube held at $37^{\circ} \mathrm{C}$ in a water bath. Two hundred microliters of kaolin was added and the stopwatch was started. The mixture was incubated for $20 \mathrm{~min}$ with occasional shaking, and then $200 \mu \mathrm{l}$ of $\mathrm{CaCl}_{2}$ was added and the clotting time was recorded with a second stopwatch. The procedure was repeated with a mixture of $100 \mu \mathrm{l}$ of platelet-poor test plasma and $100 \mu \mathrm{l}$ of platelet-rich normal plasma. Lactate dehydrogenase (LDH) assay was conducted on random donor platelet samples as follows. Random donor platelets $(1 \mathrm{ml})$ were centrifuged at $3000 \times g$ for $5 \mathrm{~min}$. The supernatant was used to quantify the LDH by semi-automated Microlab 300 (Merck Specialties Pvt. Ltd, Goa, India). Glucose determination was done by centrifuging $2 \mathrm{ml}$ of random donor platelets in fluoride oxalate vial at $3000 \times g$ for $5 \mathrm{~min}$. The supernatant was used to quantify the glucose by Erbachem 5 Plus analyzer (Erba diagnostic Mannhein Gmbh, Mannhein, Germany). The $\mathrm{pH}$ of all samples was assessed immediately after sampling at a temperature of 
$24^{\circ} \mathrm{C}$ by Compla pH meter (Composite Lab Line Pvt. Ltd, Lucknow, India). Platelet aggregation was determined by optical method ${ }^{[6]}$ using a flat-bottom aggregometer (Chornolog Corporation, Havertown, PA, USA). Briefly, the aggregometer was switched on about $30 \mathrm{~min}$ before the tests to be performed to allow the heating block to warm up to $37^{\circ} \mathrm{C}$. Stirring speed was set to $1200 \mathrm{rpm}$. Four hundred and ninety-five microliters of PRP was pipetted into the cuvette. The cuvette was placed into the heating block for incubation. After $1 \mathrm{~min}$, a stirrer was added to the cuvette containing PRP. Transmission was set to 0 on the chart recorder. One hundred percent transmission was set using the cuvette containing PPP or normal saline. PRP was allowed to warm up to $37^{\circ} \mathrm{C}$ for 2 min and then $2.5 \mu \mathrm{l}$ adenosine diphosphate (ADP) was added to make the final concentration of $5 \mu \mathrm{mol} / 1$. Change in absorbance was noted until the response reached a plateau for $5 \mathrm{~min}$. If no release was obtained, the ADP concentration was increased until a satisfactory response was obtained. Optical density of PRP was measured at $630 \mathrm{~nm}$ and adjusted between 0.75 and 0.80 , which corresponds to a cell count of $2 \times 10^{8}$ cells $/ \mathrm{ml}$ for very high PRP count. The count was adjusted by diluting the PRP in the PPP. PLT of less than $2 \times 10^{8}$ cells $/ \mathrm{ml}$ gives rise to diminished aggregation responses. The control PRP was also diluted in the same count and tested for comparison. The anhydrous sodium salt of ADP (Amresco, Solon Ind. Pkwy. Solon, OH, USA) was used as agonist. Stock solution was prepared by dissolving $5.07 \mathrm{mg}$ of disodium salt in $1 \mathrm{ml}$ of $0.9 \%$ normal saline, which was made to $10 \mathrm{mM} / \mathrm{ml}$. This was stored at $80^{\circ} \mathrm{C}$ until use. For aggregation testing, $5 \mu \mathrm{M} / \mathrm{ml}$ solution was prepared.

Aerobic culture was performed for all the samples on day 0 , day 5 , and day 7 using direct plating and Robertson Cook medium (RCM) simultaneously. In direct plating, $25 \mu \mathrm{l}$ samples were streaked on nutrient agar plate and MacConkey agar and incubated at $37^{\circ} \mathrm{C}$ for $48 \mathrm{~h}$. If growth occurred in the medium, further identification of bacterial species was done by using standard laboratory techniques, ${ }^{[7]}$ and if no growth occurred, then the sample was considered as sterile. In RCM, we placed a drop containing $25 \mu \mathrm{l}$ of sample on RCM and the plate was incubated for $72 \mathrm{~h}$ at $37^{\circ} \mathrm{C}$. When turbidity was observed in the sample, it was further processed according to direct plating method. Further result of RCM method was matched with the result of direct plating to ensure whether our direct plating method was performed correctly or not.

\section{Statistical analysis}

All the statistical analyses were done using Statistical Package for Social Sciences (SPSS) version 15.0. Data were reported as means \pm standard deviation (SD). To compare within-group differences at different time and temperature conditions, paired " $t$ "-test was used. The confidence level of the study was kept at $95 \%$, hence " $p$ " $<0.05$ indicated a statistically significant difference.

\section{RESULTS}

Out of total 150 samples, 148 samples were analyzed and 2 were discarded due to bacterial contamination. The two samples were kept in the same condition as the others. Contamination may be due to inadequate cleaning at the venipuncture site. The contamination was discovered in plasma on the $7^{\text {th }}$ day of storage period.

\section{Platelet functions without additive solution (plasma)}

On comparison, the mean value of normal level of PLT on day 5 was $250 \pm 36 \mathrm{~m} / \mathrm{mm}^{3}$ at $22^{\circ} \mathrm{C}$. No significant difference was found on day 7 at $22^{\circ} \mathrm{C}$ and $18^{\circ} \mathrm{C}$, but significant difference was found on day $7(p<0.001)$ at $16^{\circ} \mathrm{C}$. MPV on day 5 was $4.70 \pm 0.46 \mathrm{fl}$ at $22^{\circ} \mathrm{C}$. No significant difference was found on day 7 at $22^{\circ} \mathrm{C}, 18^{\circ} \mathrm{C}$, and $16^{\circ} \mathrm{C}$. On comparison, the mean value of normal level of PDW on day 5 was $5.78 \pm 0.79$ at $22^{\circ} \mathrm{C}$. No significant difference was found on day 7 at $22^{\circ} \mathrm{C}, 18^{\circ} \mathrm{C}$, and $16^{\circ} \mathrm{C}$. The mean value of PF 3 on day 5 was $2 \pm 1 \mathrm{sec}$ at $22^{\circ} \mathrm{C}$. PF 3 was constant on day 7 at $22^{\circ} \mathrm{C}$ compared with that on day 5. No significant difference was observed on day 7 at $18^{\circ} \mathrm{C}$, but a significant difference was observed on day 7 at $16^{\circ} \mathrm{C}(p<0.001)$. The normal level of $\mathrm{pH}$ on day 5 was $7.14 \pm 0.05$ at $22^{\circ} \mathrm{C}$. No significant difference was found on day 7 at $22^{\circ} \mathrm{C}, 18^{\circ} \mathrm{C}$, and $16^{\circ} \mathrm{C}$. The mean value of normal level of $\mathrm{LDH}$ on day 5 was $137 \pm 12 \mathrm{U} / 1$ at $22^{\circ} \mathrm{C}$. No significant difference was found on day 7 at $22^{\circ} \mathrm{C}$ and $18^{\circ} \mathrm{C}$. Only a significant difference was found at $16^{\circ} \mathrm{C}(p<0.001)$ on day 7 . The mean value of normal level of glucose on day 5 was $13.46 \pm 1.13$ $\mathrm{mmol} / \mathrm{l}$ at $22^{\circ} \mathrm{C}$. No significant difference was found at $22^{\circ} \mathrm{C}$ and $18^{\circ} \mathrm{C}$ on day 7 . A significant difference was found at $16^{\circ} \mathrm{C}(p<0.001)$ on day 7 of storage period. The normal level of platelet aggregation on day 5 was $70 \pm 4 \%$ at $22^{\circ} \mathrm{C}$. A significant difference was found at $16^{\circ} \mathrm{C}(p<0.001)$ on day 7 of storage period [Table 1].

\section{Platelet functions in platelet additive solution}

The mean value of normal level PLT on day 5 was $248 \pm 36 \mathrm{~m} / \mathrm{mm}^{3}$ at $22^{\circ} \mathrm{C}$. No significant difference was found on day 7 at $22^{\circ} \mathrm{C}, 18^{\circ} \mathrm{C}$, and $16^{\circ} \mathrm{C}$. MPV with additive solution on day 5 was $5.35 \pm 0.80 \mathrm{fl}$ at $22^{\circ} \mathrm{C}$. Only significant difference was found on day 7 at $16^{\circ} \mathrm{C}(p<0.001)$ of MPV. On comparison, the mean value of normal level of PDW on day 5 was $5.61 \pm 0.49$ at $22^{\circ} \mathrm{C}$. No significant difference 
was found on day 7 at $22^{\circ} \mathrm{C}, 18^{\circ} \mathrm{C}$, and $16^{\circ} \mathrm{C}$. PF 3 release on day 5 was $2 \pm 1 \mathrm{sec}$ at $22^{\circ} \mathrm{C}$. PF 3 was constant on day 7 at $22^{\circ} \mathrm{C}$ and $18^{\circ} \mathrm{C}$, but significant difference was observed on day 7 at $16^{\circ} \mathrm{C}(p<0.001)$. $\mathrm{pH}$ on day 5 was $7.09 \pm 0.04$ at $22^{\circ} \mathrm{C}$. No significant difference was found on day 7 at all the temperatures. LDH with additive solution on day 5 was $141 \pm 6 \mathrm{U} / 1$ at $22^{\circ} \mathrm{C}$. No significant difference was found on day 7 at all the temperatures. The mean value of normal level of glucose on day 5 was $11.59 \pm 1.12 \mathrm{mmol} / \mathrm{l}$ at $22^{\circ} \mathrm{C}$. Only statistically significant difference was found on day 7 at $16^{\circ} \mathrm{C}(p<0.001)$ of glucose. Platelet aggregation on day 5 was $60 \pm 6 \%$ at $22^{\circ} \mathrm{C}$. A statistically significant difference in platelet aggregation was found on day 7 at $16^{\circ} \mathrm{C}(p<0.001)$ [Table 2].

\section{DISCUSSION}

Survival of platelets, like that of all other living systems, depends on the maintenance of a delicate biochemical balance between different substances including, in particular, glucose and hydrogen ions. ${ }^{[8]}$ The quality of platelets during storage is influenced by various factors such as the preparation method, composition of the storage bag, additive solutions, temperature, PLT, and the requirement for adequate $\mathrm{O}_{2}$ to maintain aerobic metabolism. ${ }^{[9]}$ Platelets are stored with continuous gentle agitation, which is thought to enhance the transport of gases such as $\mathrm{O}_{2}$ and $\mathrm{CO}_{2}$ through the storage container. ${ }^{[10]}$

Platelet additive solutions can be used as a substitute for plasma in order to recover plasma for other purposes, to avoid transfusion of large volumes of plasma to patients, to improve storage conditions, and to make possible photochemical treatment for viral inactivation of PCs ${ }^{[11]}$ Currently, several platelet additive solutions for long-term platelet storage have been introduced. Storing platelets in additive solution containing magnesium and potassium (PASIIIM) improves the functionality of the platelets, as measured by glycolysis, $\mathrm{pH}$, morphology, adenosine triphosphate (ATP), and CD62 expression, ${ }^{[12]}$ and may allow a reduction of the amount of plasma required to be carried over to the final unit, facilitating some methods of viral inactivation and making available greater amounts of plasma for other needs. ${ }^{[13]}$ Platelet additive solution replaces $70-80 \%$ of the plasma in the original platelet unit; the final medium contains 20-30\% donor plasma. ${ }^{[14]}$ In 2006, an American Association of Blood Banks (AABB) bulletin was published stating that one potential transfusion-related acute lung injury risk reduction strategy is to store platelets in platelet additive

Table 1: Comparison of the parameters of random donor platelets stored for 7 days at different temperatures without platelet additive solution

\begin{tabular}{|c|c|c|c|c|c|}
\hline \multirow[t]{2}{*}{ Parameter } & \multirow{2}{*}{$\begin{array}{l}\text { Platelet on day } 0 \\
222^{\circ} \mathrm{C}\end{array}$} & \multirow{2}{*}{$\begin{array}{l}\text { Platelet on day } 5 \\
222^{\circ} \mathrm{C}\end{array}$} & \multicolumn{3}{|c|}{ Platelet on day 7} \\
\hline & & & $22^{\circ} \mathrm{C}$ & $18^{\circ} \mathrm{C}$ & $16^{\circ} \mathrm{C}$ \\
\hline Platelet count $\left(\mathrm{m} / \mathrm{mm}^{3}\right)$ & $254 \pm 72$ & $250 \pm 36$ & $243 \pm 26$ & $240 \pm 25$ & $208 \pm 22(p<0.001)$ \\
\hline MPV (fl) & $4.47 \pm 0.48$ & $4.70 \pm 0.46$ & $5.18 \pm 0.53$ & $5.99 \pm 0.69$ & $6.40 \pm 0.74$ \\
\hline PDW (fl) & $5.42 \pm 0.78$ & $5.78 \pm 0.79$ & $6.85 \pm 0.72$ & $7.03 \pm 0.78$ & $7.75 \pm 0.59$ \\
\hline PF 3 (sec) & $1 \pm 1$ & $2 \pm 1$ & $2 \pm 1$ & $3 \pm 1$ & $4 \pm 1(p<0.001)$ \\
\hline LDH (U/l) & $133 \pm 12$ & $137 \pm 12$ & $140 \pm 12$ & $144 \pm 19$ & $189 \pm 13(p<0.001)$ \\
\hline $\mathrm{pH}$ & $7.15 \pm 0.05$ & $7.14 \pm 0.05$ & $7.13 \pm 0.05$ & $7.13 \pm 0.05$ & $7.12 \pm 0.04$ \\
\hline Glucose (mmol/l) & $14.18 \pm 1.48$ & $13.46 \pm 1.13$ & $12.40 \pm 1.08$ & $11.83 \pm 1.21$ & $6.68 \pm 1.36(p<0.001)$ \\
\hline Platelet aggregation $\%$ (5 $\mu \mathrm{M}$ ADP) & $72 \pm 3$ & $70 \pm 4$ & $67 \pm 3$ & $62 \pm 2$ & $40 \pm 3(p<0.001)$ \\
\hline
\end{tabular}

Abbreviations: MPV: Mean platelet volume; PDW: Platelet distribution width; PF 3: Platelet factor 3; LDH: Lactate dehydrogenase; ADP: Adenosine diphosphate

Table 2: Comparison of the parameters of random donor platelets stored for 7 days at different temperatures in platelet additive solution

\begin{tabular}{|c|c|c|c|c|c|}
\hline \multirow[t]{2}{*}{ Parameter } & \multirow{2}{*}{$\begin{array}{l}\text { Platelet on day } 0 \\
222^{\circ} \mathrm{C} \\
\end{array}$} & \multirow{2}{*}{$\begin{array}{l}\text { Platelet on day } 5 \\
\qquad 22^{\circ} \mathrm{C}\end{array}$} & \multicolumn{3}{|c|}{ Platelet on day 7} \\
\hline & & & $22^{\circ} \mathrm{C}$ & $18^{\circ} \mathrm{C}$ & $16^{\circ} \mathrm{C}$ \\
\hline Platelet count $\left(\mathrm{m} / \mathrm{mm}^{3}\right)$ & $249 \pm 27$ & $248 \pm 26$ & $245 \pm 26$ & $241 \pm 21$ & $234 \pm 20$ \\
\hline MPV (fl) & $5.00 \pm 0.82$ & $5.53 \pm 0.80$ & $5.64 \pm 0.73$ & $6.09 \pm 0.84$ & $7.55 \pm 0.77(p<0.001)$ \\
\hline PDW (fl) & $5.18 \pm 0.54$ & $5.61 \pm 0.49$ & $6.13 \pm 0.50$ & $6.53 \pm 0.49$ & $7.36 \pm 0.59$ \\
\hline PF 3 (sec) & $2 \pm 1$ & $2 \pm 1$ & $2 \pm 1$ & $2 \pm 1$ & $5 \pm 1(p<0.001)$ \\
\hline LDH (U/l) & $138 \pm 5$ & $141 \pm 6$ & $144 \pm 6$ & $146 \pm 6$ & $153 \pm 8$ \\
\hline $\mathrm{pH}$ & $7.10 \pm 0.10$ & $7.09 \pm 0.04$ & $7.08 \pm 0.04$ & $7.08 \pm 0.04$ & $7.06 \pm 0.05$ \\
\hline Glucose $(\mathrm{mmol} / \mathrm{l})$ & $12.52 \pm 1.54$ & $11.59 \pm 1.12$ & $10.96 \pm 1.11$ & $10.38 \pm 1.09$ & $7.60 \pm 1.28(p<0.001)$ \\
\hline Platelet aggregation $\%(5 \mu \mathrm{M}$ ADP $)$ & $65 \pm 7$ & $60 \pm 6$ & $54 \pm 5$ & $52 \pm 5$ & $35 \pm 6(p<0.001)$ \\
\hline
\end{tabular}

Abbreviations: MPV: Mean platelet volume; PDW: Platelet distribution width; PF 3: Platelet factor 3; LDH: Lactate dehydrogenase; ADP: Adenosine diphosphate

Biomed J Vol. 37 No. 4

July - August 2014 
solution. ${ }^{[15]}$ These storage solutions allow a reduction of approximately two-thirds of the plasma volume transfused with platelets. Additionally, platelet additive solution or saline may be useful as washing solutions in reducing the frequency and/or severity of adverse reactions associated with the transfusion of plasma in platelet components. ${ }^{[16,17]}$ Therefore, there is increasing interest in developing platelet additive solutions that can be used with even further reduced levels of residual plasma.

Platelet can be prepared by random donor platelets, apheresis, and by pooling of platelet units. ${ }^{[3]}$ Random donor platelets were used in the present study. As per the guidelines of blood bank, random donor platelets are routinely stored in plasma for 5 days at $22^{\circ} \mathrm{C} \cdot{ }^{[18]}$ Due to these storage conditions, platelets have limited availability. We, therefore, carried out a study investigating random donor platelets stored at lower temperature to evaluate the influence of prolonged storage on platelet function and metabolism and minimizing the chances of bacterial proliferation at lower temperature. In the present study, platelet swirling was present in all the units at $22^{\circ} \mathrm{C}, 18^{\circ} \mathrm{C}$, and $16^{\circ} \mathrm{C}$ on day 7 in both the groups with and without platelet additive solution. Temperature below $15^{\circ} \mathrm{C}$ causes resting platelets to rapidly change from disk to spidery forms. ${ }^{[19]}$ The reduction in viability after storage at lower temperature correlates with a reduction in the number of discoid platelets. Hence, the temperature of $16^{\circ} \mathrm{C}$ was chosen in order to eliminate the above factors. Gottschall et al. reported that all the platelet concentrates from normal donors were stored for 3 days under identical conditions except for the temperatures of storage, ${ }^{[20]}$ which were maintained at $21^{\circ} \mathrm{C} \pm 0.5^{\circ} \mathrm{C}, 19.5^{\circ} \mathrm{C} \pm 0.5^{\circ} \mathrm{C}$, and $18^{\circ} \mathrm{C} \pm 0.5^{\circ} \mathrm{C}$, respectively. Immediate posttransfusion recovery of the stored platelets determined by $51 \mathrm{Cr}$ labeling averaged $47 \%, 47 \%$, and $48 \%$ after storage at $21^{\circ} \mathrm{C}, 19.5^{\circ} \mathrm{C}$, and $18^{\circ} \mathrm{C}$, respectively (differences not significant). Mean life span of the transfused platelets, however, was 8.12, 5.12, and 1.85 days at $21^{\circ} \mathrm{C}, 19.5^{\circ} \mathrm{C}$, and $18^{\circ} \mathrm{C}$, respectively. The difference between the mean life span following storage at $21^{\circ} \mathrm{C}$ and $18^{\circ} \mathrm{C}$ was significant $(p<0.03)$. They found that the platelet viability is compromised after storage for 3 days at $18^{\circ} \mathrm{C}$ and, possibly, $19.5^{\circ} \mathrm{C}$. The parameters analyzed showed that reduction in viability after storage at the lower temperature correlated with the reduction in the number of discoid platelets.

Ensuring the absence of bacterial contamination of platelet concentrates shall benefit the prolongation of the shelf life of platelet concentrates. Platelets are particularly susceptible to bacterial growth due to their having to be stored at $22^{\circ} \mathrm{C}$, and therefore, negative bacterial culturing of platelets on day 2 or day 3 of storage would be advantageous for the extension of their shelf life. Increasing platelet concentrates' storage for more than 5 days is only permitted if bacterial contamination can be excluded. In our study, only two samples showed bacterial contamination on day 7 at $22^{\circ} \mathrm{C}$ without additive solution, although no bacterial contamination was observed at $18^{\circ} \mathrm{C}$ and $16^{\circ} \mathrm{C}$ on day 7 . In platelet additive solution; we observed no bacterial contamination on day 7 at $22^{\circ} \mathrm{C}, 18^{\circ} \mathrm{C}$, and $16^{\circ} \mathrm{C}$.

Recently platelet indices such as PLT, MPV, PDW, and platelet-large cell ratio (P-LCR) have been used as markers for the quality control of PCs, as these reflect storage-induced shape changes in platelets. In our study, PLT was maintained at $22^{\circ} \mathrm{C}$ and $18^{\circ} \mathrm{C}$, but significantly decreased on day 7 in plasma when stored at $16^{\circ} \mathrm{C}$. In platelet additive solution, PLT was maintained at all the temperatures on day 7 of storage period. We observed that MPV was minimally increased in random donor platelet on day 7 in plasma at all the temperatures. In platelet additive solution, we observed that MPV level was significantly increased at $16^{\circ} \mathrm{C}$ on day 7 of storage period. In the present study, we observed that PDW increased in random donor platelet on day 7 at all the temperatures in both the groups with and without platelet additive solution.

PF 3 may also be released by antiplatelet antibodies. However, the kaolin test has the important advantage of extreme simplicity both in apparatus and performance. Hence, it is valuable to do a more rigorous standardization of the kaolin test, with an attempt to narrow the observed normal range and, thus, improve clinical discrimination. The two mixtures (platelet-rich test plasma and platelet-poor normal plasma) differ only in the platelets they contain, and clotting time should not differ by more than 2 or $3 \mathrm{sec}$. A prolongation of the clotting time of the mixture containing the test platelet compared to that containing the normal platelets is an evidence of reduced PF 3 availability. It is desirable to measure the clotting times of mixture of platelet-rich and platelet-poor samples of the test plasma and normal plasma, respectively. In the present study, PF 3 test variation was $3 \mathrm{sec}$ at $22^{\circ} \mathrm{C}, 18^{\circ} \mathrm{C}$, and $16^{\circ} \mathrm{C}$ even on day 7 in plasma and platelet additive solution.

The enzyme LDH as an intracellular enzyme is often used as a marker of tissue breakdown. In the present study, it was observed that the LDH level slightly increased on day 7 in random donor platelets with and without additive solution, and also that the level of LDH was maintained on day 7 at $22^{\circ} \mathrm{C}, 18^{\circ} \mathrm{C}$, and $16^{\circ} \mathrm{C}$. Among the metabolic parameters, $\mathrm{pH}$ showed a significant fall over 7 days of storage. Fall in $\mathrm{pH}$ may affect the quality of final platelet product. The $\mathrm{AABB}^{[21]}$ recommended that platelets with $\mathrm{pH}<6.2$ should not be used for transfusion, and in Europe, the same recommendation applies to platelets with $\mathrm{pH}>7.4 .{ }^{[22]}$ As per the Drug and Cosmetics Act of India, ${ }^{[23]}$ minimum $\mathrm{pH}$ should not be $<6.0$ at any given day of storage. If the $\mathrm{pH}$ falls below 6.0 or rises above 7.4 , a disk to sphere transforma- 
tion of the platelets takes place, resulting in marked loss of recovery in vivo upon transfusion. ${ }^{[24]}$ In the present study, we observed that the $\mathrm{pH}$ value decreased and was maintained within acceptable range on day 7 at all the temperatures in the storage period of both the groups with and without platelet additive solution.

The following three major points are essential to maintain good platelet quality in the production and storage of platelet concentrates. First, the activation of platelets during collection, preparation, and storage of platelet concentrates should be prevented or at least reduced to a very low level. Secondly, the level of glycolytic activity, the anaerobic consumption of glucose, and production of lactate should be kept to a minimum level. Thirdly, at least some glucose should be present in the platelet concentrates throughout the whole storage period. ${ }^{[25]}$ In the present study, the glucose level slightly decreased in random donor platelets with and without additive solution on day 7 at $22^{\circ} \mathrm{C}, 18^{\circ} \mathrm{C}$, and $16^{\circ} \mathrm{C}$.

Platelet aggregometry was developed in the early $1960 \mathrm{~s}$ and soon became regarded as the "gold standard" of platelet function testing. ${ }^{[26]}$ This is still the most widely used test for identifying and diagnosing platelet function defects and can be performed by commercially available multichannel aggregometers. One of the most common methods of measuring platelet aggregation is called optical platelet aggregation. This technique, which is a high-complexity laboratory test, involves adding an aggregating agent (e.g. ADP, epinephrine, thrombin, arachidonic acid) to PRP, a turbid platelet-rich suspension derived from whole blood. The effect of the aggregating agent on the suspension's light transmittance is then measured to assess platelet aggregation [Figure 1]. ${ }^{[6]}$ In the present study, we observed that platelet aggregation was slightly decreased in random donor platelets on day 7 at $22^{\circ} \mathrm{C}$ and $18^{\circ} \mathrm{C}$ in plasma and platelet additive solution, but was markedly decreased at $16^{\circ} \mathrm{C}$ in plasma and platelet additive solution on day 7 of the storage period. Kiraly et al., (2006) ${ }^{[27]}$ studied the functional viability parameters of single donor platelets for 5 days at room temperature with agitation. They also assessed a number of in vitro

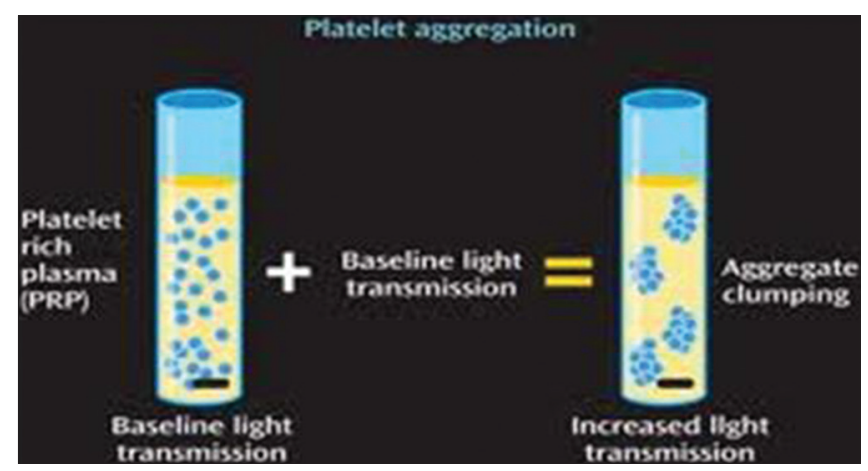

Figure 1: The in vitro platelet aggregometry assay begins by measuring the optical density of platelet-rich plasma. parameters $(\mathrm{pH}$, morphology, platelet volume distribution, osmotic recovery, aggregation, and platelet associated $\mathrm{IgG}$ ) as a function of storage time of platelets. During the first $24 \mathrm{~h}$ of storage, minimal changes were observed in the test parameters with the exception of ADP-induced aggregation $[75 \%$ decrease $(10 \mu \mathrm{M})$ and $84 \%$ decrease $(5 \mu \mathrm{M})]$. Significant difference was observed between day-0-old and day-5-old single donor platelets in all the parameters.

\section{Conclusion}

Platelets can be stored for 7 days at a slightly lower temperature of $18^{\circ} \mathrm{C}$ in plasma. We concluded that platelet storage at $18^{\circ} \mathrm{C}$ maintains platelet functions adequately. Bacterial contamination, which is the major problem in platelet storage, was seen at $22^{\circ} \mathrm{C}$. Lower temperature of $18^{\circ} \mathrm{C}$ showed no bacterial contamination. It was further observed that platelet functions deteriorated at $16^{\circ} \mathrm{C}$, hence this temperature was not suitable for platelet storage. Platelet functions were better maintained when platelet additive solution was used. Storage at $22^{\circ} \mathrm{C}$ for 7 days showed optimum platelet function with no bacterial contamination. It was observed that additive solution helped in maintaining the platelets' functions on the $7^{\text {th }}$ day with lesser variation from the control value. Platelet functions were maintained better in indigenously prepared additive solution as compared to plasma. The shelf life of platelets can be increased to 7 days if they are stored in additive solution. Random donor platelets' functions are better maintained in platelet additive solution as compared to plasma at a lower temperature of $18^{\circ} \mathrm{C}$ but not at $16^{\circ} \mathrm{C}$, on the $7^{\text {th }}$ day.

\section{Acknowledgment}

We are grateful to the Council of Science and Technology, Lucknow, Uttar Pradesh, for funding this work.

\section{REFERENCES}

1. Singh H, Chaudhary R, Ray V. Platelet indices as quality markers platelet concentrates during storage. Clin Lab Haematol 2003;25:307-10.

2. Gulliksson $\mathrm{H}$. Additive solutions for the storage of platelets for transfusion. Transfus Med 2000;10:257-64.

3. Saran RK. Transfusion medicine technical manual, $2^{\text {nd }}$ ed. New Delhi, India: WHO; 2003.

4. Zammit V. In vitro assessment of platelets stored for seven days in a platelet additive medium- a pilot study. Biomed Sci 2006;121:46-50.

5. Hardisty RM, Hutt on RA. The Kaolin Clott ing time of PRP: A test of PF-3 availability. Br J Hematol 1965;11:258-60.

6. Kandice KM. Importance of platelets and platelet response in acute coronary syndromes. Cleve Clin J Med 2009;76:S2-7.

7. Forbes BA, Sahm DF, Weissfeld AS: Bailley and Scott's diagnostic microbiology, $10^{\text {th }}$ ed. St. Louis (CV): Mosby; 1998. 
8. Amorini AM, Tuttobene M, Lazzarino G, Denti G. Evaluation of biochemical parameters in platelet concentrates stored in glucose solution. Blood Transfus 2007;5:24-32.

9. Stroncek DF, Rebulla P. Platelet transfusions. Lancet 2007;370:427-38.

10. Murphy S, Gardner FH. Platelet storage at 22 degrees C: Role of gas transport across plastic containers in maintenance of viability. Blood $1975 ; 46: 209-18$.

11. Gulliksson H. Platelet storage media. Transfus Apher Sci 2001;24:241-4.

12. De Wildt-Eggen J, Schrijver JG, Bins M, Gulliksson H. Storage of platelets in additive solutions: Effects of magnesium and/or potassium. Transfusion 2002;42:76-80.

13. Gulliksson H, AuBuchon JP, Vesterinen M. Storage of platelets in additive solution: A pilot invitro study of the effects of potassium and magnesium. Vox Sang 2002;82:131-6.

14. De Wildt-Eggen J, Nauta S, Schrijver JG, van Marwijk Kooy M, Bins M, van Prooijen HC. Reactions and platelet increments after transfusion of platelet concentrates in plasma or an additive solution: A prospective, randomized study. Transfusion 2000;40:398-403.

15. Strong DM, Shoos Lipton K. Transfusion-related acute lung injury. AABB Association Bulletin 06-07. Bethesda (MD): American Association of Blood Banks; 2006

16. Heddle NM, Blajchman MA, Meyer RM, Lipton JH, Walker IR, Sher GD, et al. A randomized controlled trial comparing the frequency of acute reactions to plasma removed platelets and prestorage WBC-reduced platelets. Transfusion 2002;42:556-66.

17. Vo TD, Cowles J, Heal JM, Blumberg N. Platelet washing to prevent recurrent febrile reactions to leucocyte-reduced transfusion. Transfus Med 2001;11:45-7.

18. American Association of Blood Bank. Standards for blood banks and transfusion services, 23 $3^{\text {rd }}$ ed. Bethesda, Maryland: Blackwell; 2004.

19. Winokaur R, Hartwig JH. Mechanism of shape change in chilled human platelets. Blood 1995;85:1796-804.

20. Gottschall JL, Rzad L. Studies of the minimum temperature at which human platelets can be stored with full maintenance of viability. Transfusion 2003;26:460-2.

21. Sweeney J. Quality assurance and standards for red cells and platelets. Vox Sang 1998;74:201-15.

22. Recommendation No. R (95) 15 . Guide to the preparation, use and quality assurance of blood components. $7^{\text {th }}$ ed. Strasbourg, France: European Council Press; 2001. p. 123.

23. Mallik V. Drug and Cosmetic Act $1940,13^{\text {th }}$ ed. Lucknow, India: EBC Publishing (P) Ltd; 2001. p. 144-51, 243-68.

24. Murphy S, Gardner FH. Platelet storage at 22 degrees C: Role of gas transport across plastic containers in maintenance of viability. Blood 1975;46:209-18.

25. Gulliksson H. Defining the optimal storage conditions for the long term storage of platelets. Transfus Med Rev 2003;17:209-15.

26. Refaai MA, Laposata M. Platelet aggregation. In: Michelson AD, editor. Platelets. San Diego: Academic Press; 2004. p. 291-6.

27. Kiraly TR, Kalish RI, Norton DF. Evaluation of apheresis platelet concentrates stored for 5 days in PL 732 bags. J Clin Apher 2006;3:178-80. 